\title{
COMPETENCE EVALUATION OF TRANSPORT MANAGEMENT SPECIALISTS: RESEARCH ON GRADUATES' ATTITUDES REGISTERED AT LABOUR EXCHANGE
}

\author{
Jolanta Skirmantiené $\dot{1}^{1}$ Kristina Vaičiūtè ${ }^{2}$ \\ Department of Social Economics and Management, Vilnius Gediminas Technical University, \\ Sauletekio al. 11, LT-10223 Vilnius, Lithuania \\ E-mails: ${ }^{1}$ jolanta.skirmantiene@vgtu.lt; ${ }^{2}$ kristina.vaiciute@vgtu.lt (corresponding author)
}

\begin{abstract}
Constantly changing labour market poses new challenges for transport management specialists. Employers require specialists characterised not only by their professional knowledge, but also capable of adapting to changing circumstances, making individual decisions, creating value added. Successful integration into labour market not only depends on external factors, such as state policies, but also on internal factors as social, personal and information competence. The conducted research enabled to assess attitudes of transport management graduates towards knowledge and competencies acquired during study process, preparedness for labour market. Research participants' attitudes enabled to distinguish the most important skills and general competencies. Research have shown that graduates most often face the shortage of practical training, financial knowledge and poor ability to develop business plans.
\end{abstract}

Keywords: manager, vocational education transport manager, competencies, human capital, managerial competence, transport management specialist.

JEL Classification: J240; J540; J530.

\section{Introduction}

Constantly changing labour market poses new challenges for transport management specialists; it is thus insufficient to acquire profession-based competencies; personal, social and intercultural competencies must be developed. According to K. Ledauskaite (2010), transport is one of the key branches of economics, therefore, this particular share of market requires professionals understanding the principles of free market, theory of modern economics and business practices, as well as being able to cooperate and communicate with domestic and international partners. In order to achieve these goals, it is necessary to improve professional competencies, accept the principles of life-long learning. A problematic question arises - how to prepare a specialist who is able to adapt to the constantly changing economic, social and cultural processes? The aim of the research is to assess attitudes of transport management graduates towards knowledge and competencies acquired during study process, preparedness for labour market. On the basis of this research, it is possible to distinguish the most important skills and general competencies, as well as to define general competence development assumptions in the study process.

The Research Object - graduates of higher education institutions, Transport Management specialty, registered at Vilnius Labour Exchange.
The Aim of the Research - to assess attitudes of Transport Management graduates towards knowledge and competencies acquired during study process, preparedness for labour market. On the basis of this research, it is possible to distinguish the most important skills and general competencies, as well as to define general competence development assumptions in the study process.

To obtain the aforementioned aim, the following objectives are set: To determine how graduates of Transport Management evaluate their preparedness for labour market, as well as levels of acquired theoretical knowledge, abilities and practical skills:

1) To distinguish the most important abilities and general competencies of Transport Management graduates.

2) To assess attitudes of Transport Management graduates towards knowledge and competencies acquired during study process, preparedness for labour market.

3) To assess graduate possibilities to integrate into Lithuanian and the EU labour market, as well as business development perspectives.

The Methodology of the Research:

1. Scientific Literature and Documentary analysis.

2. Questionnaire.

3. Statistical data analysis. 


\section{Analysis on theoretical aspects of general and managerial competencies}

The evidence of ongoing globalisation processes increases the value of human capital as the most essential factor of public economy; thus offering priority to human capital, consisting of knowledge, abilities and skills, against material or financial resources. The accumulated human capital is an important factor of the individual's income and employment-related perspectives (Gižiene, Simanavičiené 2012). Scientists S. Potelienè and Z. Tamašauskienè (2014) state that human capital promotes more rapid rate of economic growth and it is the main source of miscellaneous parts incomes and wealth oscillation. According to K. Keršienè and A. Savanevičienè (2009) success of human resources integrating in multicultural market of European labor force, which owns different training and educational systems and traditions in the field of human resources management primarily depends on individual competencies.

The conception of competence examined and analyzed by scientists L. M. Spencer, S. M. Spencer (1993), J. Gonzalez, R. Wagenaar (2003), R. E. Boyatzis (2008), J. B. Burns, J. A. Mclerney (2009), C. Wolsey et al. (2012), R. Laužackas (1997), T. Jovaiša, S. Shaw (1998), L. D. Goldstein, A. D. Davidson (1998), P. Descey, M. Tessaring (2002), D. Lepaité (2003), R. Laužackas et al. (2005), K. Pukelis, N. Pileičikienè (2010), R. Jakiūnienè, L. Rekašiūte (2011), J. Martinkienè et al. (2011) and others. Managerial competence examined by P. Lindsay, R. Stuart (1997), J. Kirby, V. Židžiūnaite (1999), H. McCredie, V. Shackleton (2000), M. M. Grzeda (2001), R. Jakiūnienè (2005), A. Čepienè (2007), J. B. Burns, J. A. Mclerney (2009), K. Ledauskaitė (2010), D. A. Whetten, K. S. Cameron (2011), E. E. Jančauskas (2011), J. Martinkienè (2014) and other scientists. The significance of competence in the activity of various organizations analyzed by P. Jucevičienè (2007).

According to A. Čepienè (2007), general competencies are formally analysed when training specialists started to raise questions on how to develop individuals in the context of globally changing environment, how to prepare an employee, who would be able to flexibly adapt to changing circumstances. According to R. Laužackas (1997), competence is a demonstration of efficient performance; ability to implement tasks in real and simulated work situations. Researchers P. Jucevičienè and D. Lepaite (2000) claims, that knowledge, abilities and skills determine the attainment of qualification, as well as the core of the competence and holistic nature are established upon assessment of the abilities that impact development, values and personal characteristics. According to the authors, competence is a human ability to act according to acquired knowledge, skills as well as attitudes, personal qualities and values. In order to assure human competence required for specific activity, it is vital to be familiarised not only with the structure of this activity, but also with its levels, accordingly, levels of competence on the basis of which the training programme should be focused on (Jucevičienè, Lepaite 2000). The variety of competence definition enables to assess this term as a set of abilities, knowledge and right to perform certain tasks. Performance results and business success depend on individual's knowledge and abilities. Modern business environment is rapidly changing, therefore, it is necessary to address contemporary requirements, determine and develop strategic competencies.

According to L. M. Spencer and S. M. Spencer (1993), J. Gonzalez, R. Wagenaar (2003), N. Longworth (2000), P. Jucevičiene (2007), it is possible to distinguish competencies required for successful operations: team-work, analytical thinking, objective-based competence, problem-solving, leadership, communication, interpersonal understanding, ability to learn, apply the acquired knowledge in practice, work independently, adapt to new situations, ability to influence.

K. Ledauskaitè (2010) states that professional competence exclusivity of transport management specialists' can be explained by the fact that specialists in this area must be able to refine on the peculiarities of transport and logistics business and justify their optimization plans and suggestions by economic calculations. Research conducted by this author have shown that the greatest issue is the shortage of practical knowledge, personal abilities and unformed personal competencies. Specialists' ability to adapt to changing market requirements and apply theoretical knowledge in practice becomes more relevant (Ledauskaite 2010).

The integration of young people into the labor market problems and peculiarities analyzed by scientists L. Okunevičiūtė Neverauskienè, A. Pocius (2001, 2005), B. Martinkus et al. (2002), R. Brazienè, U. Šalkauskiené (2012), T. F. Bradshaw (1973), N. Bontis (2006) and others. Employers around the globe constantly emphasize the importance of general competencies in business management. Successful integration into labour market not only depends on external factors, such as state policies, but also on internal factors as social, 
personal and information competence. In the modern age of information work activities are constantly changing, as much as requirements for the competence of workers are increasing. The scientist R. Jakiūnienè (2005) states that modern information society makes the demand for managers to acquire competence based on not only on professional skills, but also on informational, communicational, social, intercultural and personal. Employers require specialists characterised not only by their professional knowledge, but also capable of adapting to changing circumstances, making individual decisions, creating value added.

\section{Attitudes of transport management graduates towards knowledge and competencies acquired during study process, preparedness for labour market}

The Methodology of the Research. In order to reveal the attitudes of Transport Management graduates towards knowledge and competencies acquired during study process, assess their preparedness for labour market, the quantitative research method-questionnaire, suggested by scientists (Kardelis 1997; Tidikis 2003; Valackienè, Mikène 2010) was selected. The questionnaire was designed in accordance with accumulated material from previous scientific research. By the means of the data collection method, the selected questionnaire consists of 16 questions, divided into 4 groups. The first group of questions aims at revealing the respondents' socio-demographic information - gender, age, education. The second group of questions designed to distinguish competencies that are very important for the work of transport manager. The third group of questions purposed for hearing the attitudes of Transport Management graduates towards knowledge and competencies acquired during study process. The fourth group of questions devoted to assess graduate possibilities to integrate into Lithuanian and the EU labour market, as well as business development perspectives.

The Research Population. Young transport management specialty graduates registered at the Lithuanian Labour Exchange was selected as respondents by the method of simple random sampling. On the basis of the principle of voluntarism, the questionnaire was sent to all the young, unemployed graduates of Transport Management. Questionnaire return rate is 96.2 percent. 46 respondents from different higher education institutions (universities and colleges) took part in the questionnaire. A survey made by the use of a questionnaire was conducted in December 2015 - January 2016.

The Research Data Processing was conducted by the means of Microsoft Office Excel 2007, Microsoft Office Word 2007 and SPSS (Statistical Packet for Social Sciences 17.0) software, using descriptive statistical method. Specification of total numbers is given to questions to which it was possible to select more than one answer.

The following ethical principles were addressed: respect, voluntariness, fairness, anonymity.

The Analysis of the Research Results. In order to reveal the aim and objectives of the research, the data of the research was analysed in accordance with distinguished 4 question groups.

The first group of questions aims at revealing the respondents' socio-demographic information gender, age, education. After processing of the questionnaire data, it was determined that the majority of the respondents are males (76.6 pct.), the rest part - women ( 23.4 pct.).

46 unemployed graduates of Transport Management were interviewed. The age range of the respondents was from 22 to 29 years, and the average age -23 years.

The results showed that the majority of the respondents were the holders of the higher nonuniversity diploma (56.5 pct.), while higher university graduates comprised 43.5 pct.

The second group of questions designed to distinguish competencies that are very important for the work of transport manager.

The Research aims to ascertain the abilities and practical skills (from the perspective of the graduates) that are necessary for transport manager. As the Research have shown, it is vital for transport manager to know the following aspects:

- Principles of work planning and organization ( 82.3 pct. of university graduates),

- Communication standards in business (81.5 pct. of university graduates),

- Law on the Fundamentals of Enterprise Activities (60.1 pct. of university graduates). abilities:

College graduates identified the following

- Fundamentals of business organization (82.4 pct.),

- Basics of Management (81.5 pct.),

- Law on the Fundamentals of Enterprise Activities (60.3 pct.) (Table 1). 
Table 1. Importance of the theoretical knowledge for the work of transport manager (Source: developed by the authors)

\begin{tabular}{l|c|c}
\hline \multirow{2}{*}{ Theoretical knowledge } & \multicolumn{2}{|c}{ Graduates \% } \\
\cline { 2 - 3 } & University & College \\
\hline $\begin{array}{l}\text { Principles of work plan- } \\
\text { ning and organization }\end{array}$ & 82.3 & 52.3 \\
\hline $\begin{array}{l}\text { Communication standards } \\
\text { in business }\end{array}$ & 81.5 & 32.2 \\
\hline $\begin{array}{l}\text { Law on the Fundamentals } \\
\text { of Enterprise Activities }\end{array}$ & 60.1 & 72.3 \\
\hline $\begin{array}{l}\text { Fundamentals of business } \\
\text { organization }\end{array}$ & 43.5 & 82.4 \\
\hline Basics of Management & 51.2 & 81.5 \\
\hline
\end{tabular}

The Respondents distinguished the most important skills of transport manager:

- Negotiation management (92.4 pct. of university and 72.3 pct. of college graduates),

- Language Fluency (writing/spoken communication) in one or more foreign languages (91.6 pct. of university and 72.3 pct. of college graduates),

- Market Research (90.7 of university and 46.2 pct. of college graduates),

- Document Management (46.2 of university and 84.3 pct. of college graduates).

Additionally, the respondents assessed the most important practical skills required for transport managers' work. The Results have shown that the most required practical skills are as follows:

- The ability to assess and control situation realistically ( 96.2 pct. of university and 64.3 pct. of college graduates);

- Finding Solutions and Making Decisions (73.4 pct. of university and 62.2 pct. of college graduates);

- Computer Literacy (22.4 pct. of university and 72.3 of college graduates);

- Work Planning and Distribution (63.5 pct. of university and 43.3 pct. of college graduates) (Table 2).

In summary, it is possible to distinguish competencies, that are (in accordance with graduate attitudes) are important for the work of transport manager: Negotiation management, Language Fluency (writing/spoken communication) in one or more foreign languages, Market Research, ability to assess and control situation realistically, Work Planning and Distribution, Finding Solutions and Making Decisions.
Table 2. Importance of practical skills for the work of transport manager (Source: developed by the authors)

\begin{tabular}{l|c|c}
\hline \multirow{2}{*}{ Practikal skill } & \multicolumn{2}{c}{ Graduates \% } \\
\cline { 2 - 3 } & University & College \\
\hline $\begin{array}{l}\text { The ability to assess and } \\
\text { control situation realistically }\end{array}$ & 96.2 & 64.3 \\
\hline $\begin{array}{l}\text { Finding Solutions and } \\
\text { Making Decisions }\end{array}$ & 73.4 & 62.2 \\
\hline Computer Literacy & 22.4 & 72.3 \\
\hline $\begin{array}{l}\text { Work Planning and } \\
\text { Distribution }\end{array}$ & 63.5 & 43.3 \\
\hline
\end{tabular}

The third group of questions purposed for hearing the attitudes of Transport Management graduates towards knowledge and competencies acquired during study process. Graduate opinions and attitudes on study process organization are valuable for higher education institutions, since it may help to assess problematic areas and take measures for improvement. The results have shown, that graduates most positively evaluate the quality of the study programme, qualifications and competencies of academic - teaching staff, the use of the latest technologies in the study process, teaching methodology, learning material.

On the basis of the positive evaluations, it is possible to claim, that the quality of the studies are assured, however, respondents less positively evaluated cooperation with social partners (employers, employment agencies, other national schools, public organizations), links between theoretical knowledge and practical skills, preparedness for labour market. Higher education institutions have established social partnerships with employers; however, in order to obtain more close links between theoretical knowledge and practical skills, it is necessary to search for new cooperation forms, mutual activity principles.

The results have shown that Transport Management graduates mostly lack the following theoretical knowledge:

- Economics and Accounting (92.4 pct. of university and 80.0 pct. of college graduates);

- Awareness on Laws (92.4 pct. of university and 72.0 pct. of college graduates);

- Commerce (92.5 pct. of university and 52.5 pct. of college graduates);

- Foreign Language Skills (English, German, Russian) (73.4 pct. of university and 82.0 pct. of college graduates);

- Business Establishment Fundamentals $(32.0$ pct. of university and 60.0 pct. of college graduates) (Table 3 and Table 4 ). 
Table 3. Lack of the theoretical knowledge of university graduates (Source: developed by the authors)

\begin{tabular}{l|c|c}
\hline \multirow{2}{*}{ Theoretical knowledge } & \multicolumn{2}{|c}{ University graduates \% } \\
\cline { 2 - 3 } & Importante & $\begin{array}{c}\text { Does not } \\
\text { matter }\end{array}$ \\
\hline $\begin{array}{l}\text { Economics and } \\
\text { Accounting }\end{array}$ & 92.4 & 7.6 \\
\hline Awareness on Laws & 92.4 & 7.6 \\
\hline Commerce & 92.5 & 7.5 \\
\hline $\begin{array}{l}\text { Foreign Language } \\
\text { Skills }\end{array}$ & 73.4 & 26.6 \\
\hline $\begin{array}{l}\text { Business Establish- } \\
\text { ment Fundamentals }\end{array}$ & 32 & 68 \\
\hline
\end{tabular}

Table 4. Lack of the theoretical knowledge of college graduates (Source: developed by the authors)

\begin{tabular}{l|c|c}
\hline \multirow{2}{*}{ Theoretical knowledge } & \multicolumn{2}{|c}{ College graduates \% } \\
\cline { 2 - 3 } & Importante & $\begin{array}{c}\text { Does } \\
\text { not matter }\end{array}$ \\
\hline $\begin{array}{l}\text { Economics and Ac- } \\
\text { counting }\end{array}$ & 80 & 20 \\
\hline Awareness on Laws & 72 & 28 \\
\hline Commerce & 52.5 & 47.5 \\
\hline $\begin{array}{l}\text { Foreign Language } \\
\text { Skills }\end{array}$ & 82 & 18 \\
\hline $\begin{array}{l}\text { Business Establish- } \\
\text { ment Fundamentals }\end{array}$ & 60 & 40 \\
\hline
\end{tabular}

Respondents were also asked to assess which practical skills they mostly lack in their chosen field. The results have shown that respondents mostly lack the following practical skills in college (Table 5).

Table 5. That respondents mostly lack the following practical skills of college graduates (Source: developed by the authors)

\begin{tabular}{l|c|c}
\hline \multirow{2}{*}{ Skill } & \multicolumn{2}{|c}{ College graduates \% } \\
\cline { 2 - 3 } & Importante & $\begin{array}{c}\text { Does not } \\
\text { matter }\end{array}$ \\
\hline $\begin{array}{l}\text { how to find overseas } \\
\text { partners and work with } \\
\text { them }\end{array}$ & 90.9 & 9.1 \\
\hline $\begin{array}{l}\text { how to administer and } \\
\text { manage projects }\end{array}$ & 81.8 & 18.2 \\
\hline how to start a business & 63.6 & 36.4 \\
\hline $\begin{array}{l}\text { how to deal with con- } \\
\text { flicts at work }\end{array}$ & 18.2 & 81.8 \\
\hline $\begin{array}{l}\text { how to organize ones } \\
\text { work }\end{array}$ & 36.4 & 63.6 \\
\hline
\end{tabular}

Respondents were also asked to assess which practical skills they mostly lack in their chosen field. The results have shown that respondents mostly lack the following practical skills in university (Table 6).

Table 6 . That respondents mostly lack the following practical skills of university graduates (Source: developed by the authors)

\begin{tabular}{l|c|c}
\hline \multirow{2}{*}{ Skill } & \multicolumn{2}{|c}{ University graduates \% } \\
\cline { 2 - 3 } & Importante & $\begin{array}{c}\text { Does not } \\
\text { matter }\end{array}$ \\
\hline $\begin{array}{l}\text { how to find overseas } \\
\text { partners and work with } \\
\text { them }\end{array}$ & 36.4 & 63.6 \\
\hline $\begin{array}{l}\text { how to administer and } \\
\text { manage projects }\end{array}$ & 81.8 & 18.2 \\
\hline how to start a business & 81.8 & 18.2 \\
\hline $\begin{array}{l}\text { how to deal with } \\
\text { conflicts at work }\end{array}$ & 27.3 & 72.7 \\
\hline $\begin{array}{l}\text { how to organize ones } \\
\text { work }\end{array}$ & 18.2 & 81.8 \\
\hline
\end{tabular}

The results have shown that respondents mostly lack the following practical skills (Table 5 and Table 6):

- how to find overseas partners and work with them (36.4 pct. of university and 90.9 pct. of college graduates);

- how to administer and manage projects (81.8 pct. of university and 81.8 pct. of college graduates);

- how to start a business ( 81.8 pct. of university and $63.6 \mathrm{pct}$. of college graduates)

Practical skills that are least missing for transport management graduates:

- how to deal with conflicts at work ( 27.3 pct. of university and 18.2 pct. of college graduates);

- how to organize ones work (18.2 pct. of university graduates) (Table 7).

The calculated Pearson's chi-square test. The difference was considered statistically significant at $\mathrm{p}<0.05$.

It was found that college graduates have statistically significant $(p<0.05)$ skills shortage in the form of financial documents, cooperation with partners and the search for partners abroad.

The prospects of integrating into other EU countries in accordance with acquired qualifications were positively assessed by the majority of the college graduates (60 pct.), whereas university graduates view this possibility more pessimistic (only 40 pct.). One-third of the respondents believe 
Table 7. The comparison of graduates missing practical skills $(\mathrm{N}=46)$ (Source: developed by the authors)

\begin{tabular}{|c|c|c|c|c|}
\hline \multirow[b]{2}{*}{ Skill } & \multicolumn{2}{|c|}{ Graduates, \% } & \multirow{2}{*}{$\begin{array}{c}\text { Pearson } \\
\text { Chi-Square } \\
\chi^{2}\end{array}$} & \multirow[b]{2}{*}{$P$} \\
\hline & College & University & & \\
\hline how to find overseas partners and work with them & 36.4 & 90.9 & 7.071 & 0.008 \\
\hline how to administer and manage projects & 81.8 & 81.8 & 0.000 & 1.000 \\
\hline how to start a business & 81.8 & 63.6 & 0.917 & 0.338 \\
\hline how to participate in a competition & 54.5 & 18.2 & 3.143 & 0.076 \\
\hline how to cooperate with partners in implementing mutual work & 36.4 & 90.9 & 7.071 & 0.008 \\
\hline $\begin{array}{l}\text { how to prepare financial documentation and estimates of } \\
\text { expenditure }\end{array}$ & 27.3 & 81.8 & 6.600 & 0.010 \\
\hline how to solve conflicts at work & 27.3 & 18.2 & 0.259 & 0.611 \\
\hline how to organize ones work & 18.2 & 36.4 & 0.917 & 0.338 \\
\hline
\end{tabular}

Table 8. The prospects of integrating into other EU countries work Labour (Source: developed by the authors)

\begin{tabular}{l|c|c}
\hline \multirow{2}{*}{ Skill } & \multicolumn{2}{|c}{ University graduates \% } \\
\cline { 2 - 3 } & Yes & No \\
\hline $\begin{array}{l}\text { Of integrating into other } \\
\text { EU countries }\end{array}$ & 40 & 60 \\
\hline To start their own business & 19 & 81 \\
\hline
\end{tabular}

that in order to be employed in other EU countries, it is necessary to acquire qualifications in that particular country (Table 8).

It is important to develop entrepreneurial skills in the study process. Research results have shown, that only 20 pct. of university and college graduates are planning to start their own business, while others (80 pct.) claim that "it requires major investments", or that they "do not have enough investments" and "knowledge and experience".

Table 9. College and university graduates' knowledge and skills in self-comparison $(\mathrm{N}=46)$ (Source: developed by the authors)

\begin{tabular}{|c|c|c|c|c|}
\hline \multirow[b]{2}{*}{ Knowledge and skill } & \multicolumn{2}{|c|}{ Average rank } & \multirow{2}{*}{$\begin{array}{c}\text { Mann- } \\
\text { Whitney } \\
\chi^{2}\end{array}$} & \multirow[b]{2}{*}{$P$} \\
\hline & $\begin{array}{l}\text { College } \\
\text { graduates }\end{array}$ & $\begin{array}{l}\text { University } \\
\text { graduates }\end{array}$ & & \\
\hline $\begin{array}{l}\text { I can evaluate the business environment and my opportunities in } \\
\text { business }\end{array}$ & 12.32 & 10.68 & 51.500 & 0.530 \\
\hline I can use legislations & 13.55 & 9.45 & 38.000 & 0.111 \\
\hline I understand business as a system & 12.45 & 10.55 & 50.000 & 0.403 \\
\hline I know how to use information sources & 14.00 & 9.00 & 33.000 & $\mathbf{0 . 0 3 4}$ \\
\hline $\begin{array}{l}\text { I can analyze, organize and evaluate analytical information } \\
\text { (statistics/surveys, etc.) }\end{array}$ & 13.09 & 9.91 & 43.000 & 0.117 \\
\hline I know how to assess the company's future prospects & 13.55 & 9.45 & 38.000 & 0.125 \\
\hline I can make decisions & 12.59 & 10.41 & 48.500 & 0.382 \\
\hline I know how to develop business development strategies & 12.82 & 10.18 & 46.000 & 0.313 \\
\hline I know how to create business plans & 14.00 & 9.00 & 33.000 & 0.064 \\
\hline $\begin{array}{l}\text { I can understand the role of employees in a company and choose } \\
\text { the right employees }\end{array}$ & 12.50 & 10.50 & 49.500 & 0.439 \\
\hline I know basic bookkeeping principles & 10.77 & 12.23 & 52.500 & 0.576 \\
\hline I know the international market peculiarities & 12.73 & 10.27 & 47.000 & 0.361 \\
\hline I know how to prepare the company's annual report on the activities & 9.95 & 13.05 & 43.500 & 0.220 \\
\hline I know how to negotiate & 12.82 & 10.18 & 46.000 & 0.311 \\
\hline I know how to communicate and collaborate & 12.73 & 10.27 & 47.000 & 0.333 \\
\hline I know how to maintain the quality of the company's activities & 12.82 & 10.18 & 46.000 & 0.311 \\
\hline I can manage change & 13.14 & 9.86 & 42.500 & 0.221 \\
\hline I am able to calculate and evaluate the company's operating costs & 11.73 & 11.27 & 58.000 & 0.866 \\
\hline
\end{tabular}


Respondents were asked to assess which of the skills they have and which of them are missing. Research results have shown that university and college graduates assume, that they are able to use well information sources, they have good communicative skills, i.e., are able to communicate, cooperate, analyse, systematize and evaluate analytical content (research data, statistics), make individual decisions. A significant proportion of university graduates evaluate such skills as insufficient: establishment of business plan, evaluation of the company's future perspectives, international market peculiarities, ability to manage negotiations, ability to use legal framework, regulating the area of transport business.

The applied nonparametric statistical criteria My-Whitney (Mann-Whitney U) test for two independent samples comparison. It is found that college graduates have statistically significant $(\mathrm{p}<0.005)$ greater ability to use information sources than university graduates samples comparison (Table 9).

\section{Conclusions}

1. Research results have shown that university and college graduates assume, that they are able to use well information sources, they have good communicative skills, i.e., are able to communicate, cooperate, analyse, systematize and evaluate analytical content (research data, statistics), make individual decisions. A significant proportion of university graduates evaluate such skills as insufficient: establishment of business plan, evaluation of the company's future perspectives, international market peculiarities, ability to manage negotiations, ability to use legal framework, regulating the area of transport business.

2. The results have shown that Transport Management graduates mostly lack the following theoretical knowledge: economics and accounting, awareness on laws, commerce, foreign language skills.

3. The results have shown that respondents mostly lack the following practical skills: how to find overseas partners and work with them, how to administer and manage projects, how to start a business. Practical skills that are least missing for transport management graduates: how to deal with conflicts at work, how to organize ones work.

4. In summary, it is possible to distinguish competencies, that are (in accordance with graduate attitudes) are important for the work of transport manager: Negotiation management, Language Fluency (writing/spoken communication) in one or more foreign languages, The ability to assess and control situation realistically, finding Solutions and making Decisions, computer literacy, work planning and distribution.

5. The results have shown, that graduates most positively evaluate the quality of the study programme, qualifications and competencies of academic - teaching staff, the use of the latest technologies in the study process, teaching methodology, learning material. On the basis of the positive evaluations, it is possible to claim, that the quality of the studies are assured, however, respondents less positively evaluated cooperation with social partners (employers, employment agencies, other national schools, public organizations), links between theoretical knowledge and practical skills. Higher education institutions have established social partnerships with employers; however, in order to obtain more close links between theoretical knowledge and practical skills, it is necessary to search for new cooperation forms, mutual activity principles and need employers included in the study process, training institutions to establish practical training firms.

6. The prospects of integrating into other EU countries in accordance with acquired qualifications were positively assessed by the majority of the college graduates ( 60 pct.), whereas university graduates view this possibility more pessimistic (only 40 pct.). One-third of the respondents believe that in order to be employed in other EU countries, it is necessary to acquire qualifications in that particular country.

7. Research results have shown, that only 20 pct. of university and college graduates are planning to start their own business because the training process should be a greater focus on entrepreneurial skills development.

\section{References}

Bontis, N. 2006. Intellectual capital: an exploratory study that develops measures and models. Management Decision. $180 \mathrm{p}$.

Boyatzis, R. 2008. Competencies in the 21 century, Journal of Management Developmen 27(1): 5-12.

Bradshaw, T. F. 1973. Job seeking methods used by unemployed workers, Monthly Labor Review 96(2): 6 [online], [cited 11 January 2016]. Available from Internet:

http://search.ebscohost.com/login.aspx?direct=true $\& \mathrm{db}=$ bth $\& A \mathrm{~N}=5990286 \&$ site $=$ ehost-live 
Brazienè, R.; Šalkauskaite, U. 2012. Labour market demand and youth employment opportunities in Lithuania: content analysis of job offer ads, Economics and Management: Current Issues and Perspectives 4(28): 77-88.

Burns, J. B.; Mclerney, J. A. 2009. Career opportunities in travel and hospitality. American Hotel and Lodging Association, USA.

Čepiene, A. 2007. Development problematic of business management students core competencies: crossing of higher education and business, Vocational Education: Research and Reality 13: 48-63 [online], [cited 11 January 2016]. Available from Internet: http://esf.vdu.lt/esf/esf0013/downloads/4.pdf

Descey, P.; Tessaring, M. 2002. Training and learning for competence. Second report on vocational training research in Europe. Luxembourg: Office for Official Publications of the European Communities.

Gižienè, V.; Simanavičienè, Ž. 2012. Concept or human capital evaluation, Business Systems and Economics 2(1): 116-133 [online], [cited 15 January 2016]. Available from Internet:

https://www.mruni.eu/upload/iblock/6b1/009_gizie ne_simanaviciene.pdf

Goldstein, L. D.; Davidson, A. D. 1998. Hiring THE right stuff: using competency based selection, Compensation and Benefits Management 14(3): $1-10$.

Gonzalez, J.; Wagenaar, R. (Eds.). 2003. Tuning educational structures in Europe. Final Report. Phase One. University of Deusto, University of Groningen. $16 \mathrm{p}$.

Grzeda, M. M. 2001. Managerial competence: considerations for resolving conceptual ambiguity, in Proceedings of the $61^{\text {st }}$ Annual Meeting of the Academy of Management. 3-8 August 2001, Washington D. C.

Jakiūnienè, R. 2005. Competence of manager: requirements of the market and assessments of employers, in Republican Scientific Practical Conference "Equivalent of Trained Specialist to Market Requirements", 14 December 2005, Vilnius, Lithuania, 165-173.

Jakiūnienė, R.; Rekašiūtè, L. 2011. The significance of the general competences training preparing management professionals, in Republican Scientificpractical Conference "Studies in a Changing Business Environment”, 15 April 2011, Alytus, Lithuania. Vilnius: LEDA, 64-69.

Jančauskas, E. E. 2011. Human resources management. Vilnius: VVAM.

Jovaiša, T.; Shaw, S. 1998. Looking at the general competences training of Eastern and Central Europe, Vocational Education: Research and Reality 1: 30-47.

Jucevičienè, P. 2007. A learning city: monography. Kaunas: University of Technology. 407 p.
Jucevičienè, P.; Lepaite, D. 2000. The concept of competence, Social Sciences 1(22): 44-51.

Kardelis, K. 1997. Methodology and methods of scientific research: textbook. Kaunas: Technology.

Keršienė, K.; Savanavičienè, A. 2009. The formation and management of organizational compense based on cross-cultural perspective, Engineering Economics 21(2): 187-196.

Kirby, J.; Židžiūnaitè, V. 1999. The general skills. Vilnius: The Logotype. 102 p.

Laužackas, R. 1997. Professional curriculum reform: didactic features. Kaunas: Publishing center. 65 p.

Laužackas, R.; Stasiūnaitè, E.; Teresevičienè, M. 2005. Competency evaluation of non-formal and informal learning. Kaunas: VDU Publishing House. 50 p.

Ledauskaite, K. 2010. Economic assessment of human resource potencial in transport sector: Doctoral dissertation. Vilnius: VGTU Press "Technika" [online], [cited 7 January 2016]. Available from Internet: http://vddb.library.lt/fedora/get/LTeLABa-0001:E.02 2011 D 20110125 16261792945/DS.005.0.02.ETD

Lepaite, D. 2003. The methodology of the competence evaluation for determining development studies programs level: monograph. Kaunas: Technology. $193 \mathrm{p}$.

Lindsay, P.; Stuart, R. 1997. Reconstruing competence, Journal of European Industrial Training 21(8-9): 326-334.

Longworth, N. 2000. Making lifelong learning work: learning cities for a learning century. London: Kogan Page.

Martinkienè, J. 2014. Space of managerial competences' typologies, Journal of Management 1(24): 5162. Klaipeda: Klaipeda University Press.

Martinkienè, J.; Šaltytè, J.; Rupeikienė, L.; Viningienè, D. 2011. Assessment of professional competencies acquired at higher education school in professional activities, Studies in Modern Society 2(1): 86-95.

Martinkus, B.; Neverauskas, B.; Sakalas, A. 2002. Management: quantitative and qualitative aspects of specialist training: monography. Kaunas: Technologija. $172 \mathrm{p}$.

McCredie, H.; Shackleton, V. 2000. The unit general manager: a competency profile, Personal Review 29(1): 106-114.

Okunevičiūtè Neverauskienè, L.; Pocius, A. 2001. Competition opportunities of youth unemployed in the labour market, Philosophy. Sociology 4: 25-34.

Okunevičiūtè Neverauskienè, L.; Pocius, A. 2005. Evaluation of the economical loss caused by changes of Lithuania labor market. Monetary Studies, Theory and Practice of Economics 2: 30-46.

Potelienè, S.; Tamašauskienè, Z. 2014. Human capital conceptualization: development and concept formation, Business Systems and Economics 4(1): 89106. 
Pukelis, K.; Pileičikienè, N. 2010. Improvement of generic skills development instudy programmes of higher education: the graduates' viewpoint, The Quality of Higher Education 7: 108-131 [online], [cited 10 January 2016]. Available from Internet: http://skktg.vdu.lt/downloads/zurnalo_arch/amk_7/ qhe_2010_108_131.pdf

Spencer, L. M; Spencer, S. M. 1993. Competence at work. Hoboken, NJ: John Wiley and Sons, Inc.

Tidikis, R. 2003. Methodology of social science research. Vilnius: Lithuanian Law University, Publishing Centre.

Valackienè, A.; Mikènè, S. 2010. Social research: methodology and methods of accomplishment: textbook. Kaunas: Technology.
Whetten, D. A.; Cameron, K. S. 2011. Devloping Management skills [online]. Peerson. 720 p. [cited 18 January 2016]. Available from Internet:

http://www.wnycollegeconnection.com/documents /Skills\%20Gap/Developing\%20Management\%20S kills.pdf

Wolsey, C.; Minten, S.; Abrams, J. 2012. Human resource management in the sport and leisure industry industry [online]. Abingdon, Oxon [cited 25 January 2016]. Available from Internet: http://samples.sainsburysebooks.co.uk/978113410 2174_sample_520738.pdf 